\title{
Prostitution as a Form of Human Alienation in Vargas Llosa's The Green House
}

\author{
Bamdev Adhikari
}

\begin{abstract}
The portrayal of prostitutes as the characters and prostitution as the institution is a rampant subject in Spanish American novels since the time of the first novelist of the continent, Jose Joaquin Fernandez de Lizardi. Mario Vargas Llosa's novel The Green House portrays the women characters in pathetic exploitation, mainly sexual exploitation. The exploitation of the women in the novel is inextricably connected with the political system of Peru. The capitalist economic/ political system of Peru in the second half of the $20^{\text {th }}$ century forced women to sell their body for their survival. Prostitution is treated as an industry from which the investors or the bidders earn surplus money. My argument is that the political/economic system, capitalism is responsible for the alienation and exploitation of women in Peru in the 1960s.
\end{abstract}

Keywords: Capitalism, alienation, estrangement, exploitation, prostitute, prostitution.

\section{Introduction}

The different forms of exploitation of women portrayed in The Green House like exploitation of prostitutes by brothel owners, exploitation of wives by husbands, exploitation of indigenous girls by religious institutions, exploitation of women by the army and above all exploitation of women by men are true to the historical reality of Peru and the whole of Spanish America in the middle of the twentieth century. These exploitations are related to the material condition of $20^{\text {th }}$-century Peruvian society and hence they are the by-products of the political and economic system. In Marxist explanation, the economic and political system of the Latin American continent in the second half of the twentieth century is the bourgeois capitalist system.

Borrowing Karl Marx's terms, Robert Heilbroner enumerates three major features of capitalism: "an all-important dependency on the successful accumulation of capital, wideranging use of market mechanism and a unique bifurcation of power into two sectors, one public one private" (1321). Peru fulfilled all these three qualities in the twentieth century because, as William Glade remarked, capitalism was a European imposition and its seeds were implanted in the Latin American continent in the sixteenth century. Glade added, "Capitalism was enthroned in Latin America with the arrival of Spaniards and Portuguese" (51). Glade is right; capitalism gradually gets consolidated in the continent and in the twentieth century, Peru 
and other Latin American countries follow bourgeois/capitalistic mode of production, and prostitution as an institution is a byproduct of the economic and political system.

Marxists argue that women are exploited in the bourgeois political system. Explaining the relation between women and bourgeois mode of production, Marx and Engels, in their famous treatise The Communist Manifesto, assert that prostitution stems from bourgeois views on women. They write: "The bourgeois sees in his wife a mere instrument of production. He hears that the instrument of production are to be exploited in common, and, naturally can come to no other conclusion than that lot of being common to all will likewise fall to the women" (27).

Marx and Engels blame the bourgeoisie that they are gender-biased people and see their women from the point of view of the instrument of production. Like his fellow boom novelists of the nineteen sixties, Mario Vargas Llosa wrote about social injustices done on women by individuals as well as by institutions in capitalist Peru. The women do become the victims from the hands of the smugglers to the hands of the state army but in this essay, the emphasis is given on the women working inside the brothels. It's the institutionalized prostitution that the novelist puts in the center so as to give examples of human alienation.

When the capitalistic mode of production replaced feudalistic mode, a lot of new concepts and new terminologies came into existence. These concepts include private property, the separation of labor, capital and land, wages, profit of capital, rent of land, division of labor, competition, and exchange value and so on. The capitalistic system of production, according to Karl Marx, creates plight of the worker and "the worker sinks to the level of commodity and becomes indeed the most wretched of the commodities" (Economic and Political Manuscripts 28). The worker's labor becomes a commodity to be bought and sold at the interest of the capitalists. In other words, the capitalist is able to appropriate the labor of the worker and this appropriation of labor is what Marx calls "estrangement or alienation" (EPM 29). What the workers produce does not belong to the workers; instead, it belongs to the employers. One puts his/her efforts into the object; but the other owns the object. The workers are alienated or depersonalized; and the capitalist obtains surplus value from the worker's labor. The system sets rules in the workplace: how to work and when to work; the labor is depersonalized from the worker; and the worker comes to the situation of denying himself/herself and feels miserable. Raymond Williams comments on this condition: "The world man has made confronts him as stranger and enemy having power over him who has transformed his power to it" (35). Man's labor makes the world of the work but he who makes the world is estranged from the world itself. In this context of human alienation, the prostitutes, who offer their body to their clients for the sexual act, cannot control the act themselves. Their work becomes someone else's property for the time being estranging or alienating the women from their work (sexual activity). 
Prostitution in The Green House: Portrayal of Peruvian Reality

The novel The Green House is set in two places of Peru, Maranon basin and Piura. The first is in the Amazonian jungle area on both sides of the Maranon River, a tributary and the main source of the Amazon River with small villages of different Indian tribes, an army garrison and a mission named Santa Maria de Neiva. The second setting is a coastal town with its outskirt slum area called Mangacheria. The jungle area is the place where different agencies like the military, missionary, smugglers, government officials and various Indian tribes collide to meet their objectives. Similarly, the coastal City Piura is the place where rich people spend their luxurious life. As both places are in control of the capitalist patriarchal system, the quest for money and power guide the agencies to exploit the poor people and women alike. Though women are not safe from any man, the novelist portrays four main agencies that exploit women in the novel: the smugglers, the army, Christian missionary and the owners of the brothel.

The coastal city of Piura represents an affluent lifestyle of Peru with large buildings, coffee shops and bars. Don Anselmo, a stranger for the people of Piura, makes a real assessment of the city dwellers. Thinking the people would want more places of amenities, he builds a house of entertainment and paints it in green color, and people Christianize the house as "the Green House." The house is not only the central place from which the title of the novel is derived, but it is also the central place of women's exploitation and oppression. This is the house working as bar cum brothel accompanied by lots of musical events, for Don Anselmo "brought guitar players, bar drum players, jawbone scratchers, flutists, and bass drum and cornet players" (85). The owner himself played the harp. This house became popular in Piura and its neighboring cities for its unique type of entertainment and food. Soon the house and its activities come in confrontation with city dwellers. The senior people would say: "It was as if the air had been populated. The music penetrated everywhere; even though we could close our doors and windows, we could hear it while we ate, while we said our prayers and while we slept" (85). Similarly, the house came into collision with the church and the priests would say: "And you should have seen how it took them away from their homes and drew into the streets towards the Old Bridge" (86). In the same way, the mothers and wives would say: "And there was no use praying, over the weeping our begging, the priests' sermons, the novenas even the Holy, Holy, Holy were of no use" (86). After all, the questions why the Green House is so powerful and why the people of civil society, the senior people, the clergies and even the women are incapable of stopping its activities need comprehensive answers.

The orchestra and the delicious food of the Green House are only the things to be seen in the surface and the main attractions of the house are its interior decoration and its inhabitants, "the occupants", young girls used in sexual activities. These girls were treated as commodities on sale. First Anselmo made the house look luxurious with "six washbasins, six mirrors, six- 
chamber pots, matting, oil lamps, bright colored curtains and half a dozen beds" (84). In the same way, the girls, "the occupants", would wait for the customers in colorful outfits and "their scarves and jewelry would sparkle like crustaceans in the arid countryside" (88). In the first year, there were only four occupants and the number grew to twelve and "at its height the Green House had twenty occupants" (88). It looked like a well-managed and well-organized sex shop in Piura. The occupants sold their bodies for the surplus of the owner as if they were commodity objects put for sale in the hi-fi shop.

The people know what was happening inside the Green House but they are helpless to stop its activities. The Green House is an integral part, an agency of the capitalistic superstructure of Peru and so it is powerful. Ironically, the law of Peru has given permission to Don Anselmo to exploit young girls as sex workers. He is doing legal business with the permission of the government agencies, for, according to Lorraine Nencel, "prostitution was legal in Peru since 1910" (233). Nencel sounds logical because the activities of the Green House described in the novel take place in the 1930s. The women of Piura formed an association and made a formal complaint to the Chief of Police and the Mayor, but "the authorities agreed with their heads lowered; of course they were right, the Green House was an affront to Piura but what could they do? Don Anselmo was protected by the laws made in that corrupt capital of Lima" (86). The authorities told the women that the Green House was not against the constitution or the Criminal Code of Peru. Kaminsky rightly gives her comment on the power of the Green House, "The house is more powerful than the actuality" (47). Kaminsky signals that prostitution was a legalized institution in Peru and the police officer and Mayor, who could not go against the law, were unable to stop the activities in there.

In a country, where prostitution is legalized, the state is responsible for the exploitation of the girls in the house of prostitution. Lorraine Nencel speaks on why Peruvian Indian women enter the brothels: "They do not know how to earn money nor spend it. They always live on the edge of poverty, letting themselves be exploited; and they die in destitution" (18). The same thing happens in the Green House, too. The owner of the Green House, a capitalist entrepreneur takes advantage of the girls' poor economic condition and uses them as prostitutes. The girls have been sexually exploited like animals or objects because they have not been given individuality. They have not been given proper names and are simply called "the occupants". By giving this term to the girls in exploitation, the novelist signals that these girls are not treated as human beings but instead they are treated as the objects of consumption, as forms of the commodity. As the Green House becomes legally invulnerable, being helpless, the situation invites another confrontation and Father Garcia collects a mob and they burn the house at night. 
The occupants, the girls inside Anselmo's Green House are, of course, treated like commodity objects but nobody tries to understand why they were exploited. Nobody bothered to think why the girls were forced to earn their living by selling their bodies to the clients. On the one hand, they are forced to spend a hellish life and on the other hand, society always stigmatizes them. When the mob led by Father Garcia approaches the Green House, the girls come out of the house to save themselves. Nobody thinks of rescuing them, on the contrary, the mob begins to beat them. The novelist describes this scene:

But the shrieks were heard and just as ants desert labyrinths when flooded by the river, the occupants poured out, pushing and howling, painted and half-dressed and Father Garcia's voice rose, thundered out over the sea, and innumerable tentacles reached out from among the waves and the surf, caught the occupants, pulled them down, and beat them on the ground. (202)

In the eyes of society, the girls were prostitutes and society never welcomed them. But nobody went deep down why they became prostitutes and nobody tried to understand how they became victims of the state mechanism.

The economic, social and physical subordination of women to men started in the colonial era and continued uninterrupted. Bonifacia, an Aguaruna Indian girl, is a perfect example of such subordination portrayed in the novel. Bonifacia, who is expelled from the Christian missionary at Santa Maria de Nieva, marries a sergeant and becomes his dependent for survival. When the sergeant is imprisoned for killing a man, Bonifacia again becomes helpless. Josefino, whom the novelist characterizes as a lumpenproletariat ${ }^{*}$, takes advantage of Bonifacia's helplessness. Though he is a close friend to the sergeant, he seduces her, persuades her to abort the child and forces her to join Chunga's Green House to do the job of a sex worker. In the Green House, Bonifacia is called the Wildflower and she becomes the number one choice for the clients. Michael Moody commenting on Bonifacia's transitions to a number of places asserts that Bonifacia is a typical representative example of Indian girl's sufferings. He adds: "More like a sample than a symbol, Bonifacia's life acquires an expanded and grievous meaning in the context of Peru's social realities" (16). Moody's signal goes towards the mission which brought up Bonifacia and pushed her to the predicament of existence. In Moody's views, the Spanish nuns are responsible for the preservation of a social mechanism that introduces innocent girls to Social and moral degradation. Stephen Henighan, too, sees the social-political system responsible for the plight of girls like Bonifacia. He further says: "Though the girls receive a more comfortable upbringing in the mission, Peruvian society has

\footnotetext{
* Marxist Jargon defined by Marx and Engels in A Manifesto of the Communist Party as "a passively rotting mass thrown off by the lowest layers of society, may, here and there, be swept into the movement by a proletariat revolution.
} 
no place for pious, literate indigenous women, once they leave the mission, most, like Bonifacia, end up as prostitutes" (262). After being civilized in the mission, the Indian girls do not spend a better life; they either work as housemaids or prostitutes.

Father Garcia had burned the Green House built by Don Anselmo but after some years, another Green House appeared in another part of Piura and it was revived by Anselmo's own daughter Chunga. Father Garcia burnt the concrete Green House but he could not erase the concept and the house re-appeared as Egyptian bird Phoenix. Father Garcia's action turns out to be ironic as Kaminsky argues that by burning the Green House, Father Garcia enshrined it in the communal consciousness (47). The myth of the Green House repeats, albeit slightly in a different form giving continuity to the same job. The myth was there and the mass was eager to see the concrete Green House to give the continuation of sex shop by estranging or alienating innocent Indian girls.

The paid sexual intercourse a woman offers to a man by getting money is a form of alienation. The occupants in both old and new Green Houses sell their body in the manipulation of the brothel owners. Their work (here sexual activity) is appropriated by the brothel owners, who stand as a representative of the capitalist system because they receive the surplus money from the sexual works of the occupants. Since the occupants are not offering their body at their will, like other alienated workers, they do not have an emotional attachment to their sexual works/activities. The women cannot own their sexual activities emotionally because they have sold it to someone else. They themselves become stranger from their own body and so the sex workers are in more wretched alienation than other workers who put their labor in commodity production.

Marxist critics try to interpret prostitution as the symbol of degradation that symbolizes everything that is wrong with the wage laborer. A woman is degraded as soon as she enters the trade like other wage laborers under capitalism. If seen from the perspective of economic exploitation and coercion, workers are held to be in the same position as the prostitutes. So, general workers and prostitutes are different in form, not in the content. While critiquing prostitution, Marxist critics take their lead from Karl Marx's statement: "Prostitution is only a specific expression of the general prostitution of the laborer, and since it is a relation in which falls not the prostitution alone, but also the one who prostitutes- and the latter's abomination is still greater" ( $E P M 42)$. According to Marx, the person who makes surplus money by exploiting and coercing the workers can be compared with the "one who prostitutes." Carole Patman summarizes this relation, "Prostitution then represents economic coercion, exploitation, and alienation of the wage laborer" (58). All the occupants who work with Don Anselmo and Chunga then are the symbol of capitalistic society's exploitation, degradation and alienation. 
Talking about the places of prostitution, Nencel classifies three kinds of locales for sexual activities: houses of tolerance, brothels and hotels. Llosa's portrayal of the Green House in Piura resembles Nencel's first category of sex locale, house of tolerance, for she writes, "houses of tolerance (casas de tolerancia), where one or more women exercise prostitution permanently or temporarily and where music, dance and purchase of alcohol are permitted" (22). Anselmo's Green House was made in this model. Nencel talks about the ethnic group of the women who enter this profession: "The first are Indian women or at the most mestizas, the second are the white" (20). Similarly, she gives an explanation of why women enter this profession: "Since the beginning of the debate, women's economic situation has been acknowledged as the key push factor for entering prostitution" (15). The women who are sexually exploited in The Green House come from poor Indian tribal group, economically the most vulnerable group in Peru. They became vulnerable because of the economic and political system adopted by the state in the context of the novel, its capitalism.

\section{Conclusion: Use of Women's Body for Surplus Making}

Marxists are against any kind of exploitation done on a man by another man. The women are, no doubt, sexually exploited but there is a hidden objective behind their exploitation. Both brothel owners Don Anselmo and his daughter Chunga earn surplus money by appropriating the girls' sexual works/activities. The corrupt agents and institutions in the novel are the replications of Peru's historical reality. The portrayal of the women's exploitation in the novel suggests that the capitalist mode of production, the blind race of earning money cannot do justice to the women in Peru. The novelist gives a message that as long as there is a capitalist mode of production and distribution system, prostitution will not be eliminated and women will continue to become the victims of alienation or estrangement.

If seen from post-modern Marxist-feminist perspective, the prostitutes in The Green House are in more wretched condition than mere alienation or estrangement. Post-modern Marxistfeminists explain women's sexuality as "potential danger as well as pleasure" (Baxandal 240). Quoting Andrew Doworkin and Catherine McKinnon, Baxandal writes: "They make no distinction between rape and intercourse, marriage and prostitution and fantasy and reality" (240). Baxandal's implication is that the unowned sex is not different from rape and marriage in that condition looks like prostitution itself. If we see the condition faced by women in legal marriage from Doworkin and Mckinnon's perspective, it will be easy to imagine what the prostitute feels while offering their body to the strangers at the interest of the brothel owner. The condition goes further ahead than rape and it's more than mere alienation. Women will continue to become victims of prostitution in the capitalist mode of production and their liberation becomes possible only if Marxist and feminist work together and fight against capitalist patriarchy. Otherwise, the story of the "occupants" of the Green House will have 
32 JODEM: Journal of Language and Literature, vol. 10, no. 1, issue 12, 2019/2076BS

ceaseless succession repeating the situation look like the slogan says "the name of the game is the same."

\section{Works Cited}

Baxandall, Rosalyn. "Marxism and Sexuality: The Body as Battleground." Marxism in the Postmodern Age: Confronting the New World Order. Eds. Antonio Callari, Stephen Cullenberg and Carole Biewener. The Gulford Press, 1995, pp. 235-245.

Glade, Williams. "Latin America and the International Economy 1870-1914." The Cambridge History of Latin America, vol. 4. Ed. Leslie Bethell. Cambridge UP, 2008, pp. 1-56.

Heilbroner, Robert. "Technology and Capitalism." Social Research, vol. 64, no.3, Fall 1997, pp. 1321-1325. JSTOR, www.jstor.org/stable/40971214

Henighan, Stephan. "Mad Land, My Land: The Problem of National Identity in Vargas Llosa's La Casa Verde." Canadian Journal of Hispanic Studies, vol. 27, no.2, Winter 2003, pp. 253-270. JSTOR, www.jstor.org/stable/27763829

Kaminsky, Amy Katz. "Inhabitants, Visitors and Washerwomen: Prostitutes and Prostitution in the Novels of Mario Vargas Llosa." INTI, no. 8, 1978, pp. 45-56. JSTOR, www.jstor.org/stable/23285207

Llosa, Mario Vargas. The Green House. Trans. Gregory Rabassa. Harper Perennial, 1965.

Marx, Karl. Economic and Philosophical Manuscript of 1884. Trans. Martin Milligan. Progress Publishers, 1959.

Marx, Karl, and Fredrick Engels. A Manifesto of the Communist Party. Authorized English Translation. International Publishers, 1948.

Moody, Michael. "The Web of Defeat: A Thematic View of Characterization in Mario Vargas Llosa's La Casa Verde.” Hispania, vol.59, no.1, March 1976, pp.11-23. JSTOR, www.jstor.org/stable/339367

Nencel, Lorraine. Ethnography and Prostitution in Peru. Pluto Press, 2002.

Williams, Raymond. Keywords: A Vocabulary of Culture and Society. Oxford UP, 1983. 